\title{
Administrative Strategies of Departmental Heads as Determinants for the Effective Management of Human Resources in Tertiary Institutions in Delta State, Nigeria
}

\author{
Regina N. Osakwe ${ }^{1}$ \\ ${ }^{1}$ Department of Educational Administration and Policy Studies, Faculty of Education, Delta State University, \\ Abraka, Nigeria \\ Correspondence: Regina N. Osakwe, Department of Educational Administration and Policy Studies, Faculty of \\ Education, Delta State University, Abraka, Nigeria. Tel: 234-080-3501-0236. E-mail: \\ nonyeosakwe@yahoo.co.uk
}

Received: December 10, $2014 \quad$ Accepted: January 8, $2015 \quad$ Online Published: January 21, 2015

doi:10.5539/hes.v5n1p43

URL: http://dx.doi.org/10.5539/hes.v5n1p43

\begin{abstract}
This study investigated administrative strategies of departmental heads as determinants of effective management of human resources in tertiary institutions. Four research questions were asked and four hypotheses were formulated to guide the study. As a descriptive survey, the population comprised all the eight tertiary institutions in the state with 1898 academic staff and 4633 non-academic staff. A sample of 980 academic staff and 1550 non-academic staff was drawn through the multi-stage and stratified random sampling techniques. The instrument used was the questionnaire. Data collected were analyzed using Pearson correlation matrix, means and standard deviation, linear and multiple correlation and regression analysis. Results showed, among others, that there is significant correlation between administrative strategies and human resource management. It was recommended that departmental heads should equip themselves adequately with various administrative strategies.
\end{abstract}

Keywords: administrative strategies, human resources, departmental heads, tertiary institutions, management

\section{Introduction}

Nigeria as a developing country believes that building a knowledge-based workforce is imperative, particularly in the education sector. This is because education contributes significantly to the development of any nation physically, morally, socially, politically and economically. The basic philosophy underlying the development of the educational system in Nigeria is that every child should have educational opportunities of their kind which would allow them exhibit abilities and skills as well as contribute meaningfully to the social and economic growth of the country (FRN, 2004). Tertiary institutions of learning are vested with the responsibility of providing skilled intermediate and high-level workforce for the economy. Thus, effective management, training and development of human resources in tertiary institutions is of paramount importance. They are expected to produce a capable and skilled workforce that can effectively tackle current and future challenges by providing them with technological skills as well as critical thinking abilities.

The term management could be defined as the art of getting things done through people. In a broader sense, it is the process of planning, organizing, leading and controlling the efforts of members of an organization/institution and using all the organizational/institutional goals and objectives. Management, according to Oshionebo in Oyeniyi (2011), is the allocation of resources and inputs for the purpose of producing output desired by the customers of an organization so that corporate objectives are accomplished. The interrelated activities and functions of management include planning, organization, leadership, control and development. These actions are normally carried out by individuals (managers, administrators, organizational/institutional stakeholders, government officials, etc) within the organization/institution to achieve organizational goals and objectives. Thus, Massie in Adeyemi (2008) pointed out that one has to examine what managers do in order to identify who a manager is. He argued that management is a process of decision-making, organizing, staffing, planning, controlling, communicating and directing. In the same vein, Egwunyenga (2006) sees management as the co-ordination and integration of people and material resources to attain established objectives. It is also regarded 
as a social process designed to ensure the co-operation, participation, intervention and involvement of people in the effective achievement of a given objective. This achievement could be made through effective planning, organizing, directing, motivating, controlling, budgeting and evaluation (Adeyemi, 2008; Ajayi \& Ayodele, 2002; Fabunmi, 2000). Considering the above points, management could be seen as the technique employed when managing and carrying out the administrative and managerial functions of an institution through planning, directing, and controlling, in order to successfully accomplish its goals and objectives. Thus administrative strategies in this study are the principles of management which include planning, organizing, directing, co-ordinating, controlling and evaluating both human and non-human resources in tertiary institutions to achieve its goals and objectives.

Human resource refers to the individual manpower, humanity, people and society which are concerned with the running of an organization/institution by using their aspirations, talents, needs, abilities and capacities to achieve stated objectives. They play more essential roles in the teaching-learning situation of our tertiary institutions than other factors of production designed to attain educational goals and objectives. Human resources are the most dynamic of the entire organization/institutions because they are active in the accumulation of wealth, exploit material resources, build social, economic and political society, and carry out national development. Human resource is a product of human relations movement and the behavioural scientific management theory of the early twenty century when researchers began documenting ways of creating business value through the strategic management of workforce. Research works of Elton Mayo, Abraham Maslow, Kurt Lewin, Max Weber, Frederick Herzeberg, Douglas McGregory, Mary Follett and David McCell form the basis for studies in organizational behaviour and theory. They stressed on the importance of people in organizations, the relationship between human relations and productivity, managerial styles and employees' participation in matters affecting them and how work behaviour influences the productivity of workers (Wikipedia, 2012; Adeyemi, 2008).

In a study of Benabo, Ndiomu and Koroye (2011), it was found that all the major skills (motivation, staffing, training and development, employee's maintenance skills), of human resource management need to be emphasized by administrators in time of management. Human resource is perceived as the most vital of the resources that are at the disposal of educational enterprises. Therefore, effective management of human resources would facilitate the achievement of the educational goals and objectives of tertiary institutions. The importance of manpower to tertiary institutions cannot be over emphasized. Adewoyin (2006) states that employees are resources that should be effectively managed if organizations are to be successful. Observations indicate that the extent of managing human resources varies from one tertiary institution to another. Thus, human resource management, according to Oyedeji (2000), is a strategic and coherent approach to the management of an organization's most valued assets for effectiveness and achievement of the organization's goals and objectives. In tertiary institutions, the overall goal of human resource management is to see that students receive educational services through the efforts of school personnel/managers. This implies that personnel management services of tertiary institutions are directed towards attainment of educational objectives (student academic performance).

Therefore, it is necessary that management must recruit adequate and qualified academic and non-academic staff that will be willing and able to render effective and efficient educational services to tertiary institutions. For this reason, certain procedures and steps must be taken to provide the necessary services in schools (Tijani, 2011). These services include staff recruitment and selection, staff training and development programmes, compensation and staff welfare and, finally, performance appraisals. He also stressed the need for adequate supply and utilization of teachers with a view to ensuring the relevance and effectiveness of the school system.

Adesina (2007) sees human resource management as recruiting adequate and qualified staff, developing and maintaining the staff so that they would be willing and able to render effective and efficient educational services to students. He described human resources management as being charged with attracting, motivating, retaining and developing the right number and quality of staff. In the educational system, human resource management is a strategic and coherent approach to the management of human personnel working individually and collectively to contribute to the achievement of educational goals. Adeyemi (2008), in support of these points, enumerated the functions of the school human resource manager to include responsibilities to students and staff, financial transactions, public relations and evaluation of the school's programmes. In his study, he discovered that the level of human resource management by school principals was low; there was a better management of human resources in small schools than in large schools, and in rural schools than in urban schools. He also discovered that there was no significant difference between the management of teaching and non-teaching staff.

In order to carry out these management functions and to achieve the nation's tertiary institutions' educational goals and objectives, school managers/authorities should employ administrative strategies. These administrative strategies are components of administration used to manage human resources (academic, non-academic staff and 
students). The strategies include proper and effective leadership, discipline, supervision, planning, delegation of duties, monitoring of staff and students activities, motivation of staff, establishment of channels of communication between themselves and their staff and identification of problems. School authorities/managers should also see that students receive adequate teaching and learning through the efforts of both academic and non-academic staff. They should create a conducive environment that will encourage staff and students to actively participate in all school activities, encourage cordial relationship between all categories of staff, and give valuable suggestions to their needs. It is against this background that this study examines the administrative strategies of departmental heads as determinants of effective management of human resources in tertiary institutions.

\subsection{Statement of Problem}

Education which is the foundation of the development of human capital and a major contributor to economic and social development of a nation has been faced with perennial and persistent inadequacy of manpower. It is imperative to state here that the federal and state governments are saddled with the responsibility of recruiting and supplying academic and non-academic staff to tertiary educational institutions. Since a country depends on sound education for social and economic development, it is essential that school managers have a firm grip on their human resources.

The failure of achieving the objectives of tertiary education, as stated in the Nation Policy of Education (FRN, 2004), has been attributed to factors such as lack of commitment, lack of motivation, improper leadership, lack of effective communication, inadequate supervision, teachers ineffectiveness, lack of orientation, seminars, workshops and conferences. Among the problems are also indiscipline, unco-operative behaviour of top management, senior managers and line managers, denial of or irregular promotion of staff, frustration from government inactions, poor management policies and employees pessimistic attitudes. A cursory look at the problems confronting the management of human resources in tertiary educational institutions has made it imperative to examine the administrative strategies of departmental heads as determinants of effective management of human resources in tertiary educational institutions.

\subsection{Research Questions}

1) What is the relationship between departmental heads administrative strategies and their effective management of human resources in tertiary institutions?

2) Is there any difference between the management of academic staff and the management of non-academic staff in tertiary institutions?

3) To what extent do departmental heads' demographic factors predict their administrative strategies in tertiary institutions?

4) To what extent do departmental heads demographic factors predict their effective management of human resources in tertiary institutions?

\subsection{Hypotheses}

1) There is no significant relationship between departmental heads administrative strategies and their effective management of human resources in tertiary institutions.

2) There is no significant difference between the management of academic staff and the management of non-academic staff in tertiary institutions.

3) Departmental heads demographic factors do not significantly predict their administrative strategies in tertiary institutions.

4) Departmental heads demographic factors do not significantly predict their effective management of human resources in tertiary institutions.

\section{Methods and Materials}

The study is a descriptive survey research which employed the expost-facto design to investigate the administrative strategies of departmental heads as determinants of effective management of human resources in tertiary institutions in Delta State, Nigeria. The design chosen, involves the collection of data to answer research questions and test hypotheses about present situations of problems without manipulation of the variables or control of the situation. The population of the study comprised all the 1,898 academic staff and 4,633 non-academic staff in all the eight public tertiary institutions ( 2 universities, 2 polytechnics, 4 colleges of education). To select the sample, the population was divided into heterogeneous groups based on some 
characteristics; the multi-stage and stratified random sampling techniques were used. A sample of 980 academic staff and 1550 non-academic staff was drawn. The instrument used for the study was a questionnaire which comprised of the bio-data and 36 items on administrative strategies used for effective management of human resources. To ascertain the face and content validity of the research instrument, copies of the questionnaire were given to three experts in Educational Administration and Management, and Educational Measurement and Evaluation who are authorities in the area for scrutiny, advice and verification. Thereafter, the items in the questionnaire were modified based on the comments and suggestions from the experts. The reliability of the instrument was established using Cronbach Alpha reliability technique. A correlation coefficient value of 0.78 was obtained indicating that the instrument was reliable.

Data collected were analyzed using Pearson correlation matrix, and descriptive statistics (means and standard deviation) for answering the research questions, while linear and multiple correlation and regression analysis were used to test the hypotheses.

\section{Results}

\subsection{Research Question 1}

What is the relationship between departmental heads administrative strategies and their effective management of human resources in tertiary educational institutions?

Hypothesis 1: There is no significant relationship between departmental heads administrative strategies and their effective management of human resources in tertiary educational institutions.

In order to answer research question one and test hypothesis I, Pearson correlation matrix, the linear correlation and regression analysis were used in relation with administrative strategies and human resource management. The results obtained are presented in table 1.

Table 1. Linear Correlation and Regression of Departmental Heads Administrative Strategy and the Effective Management of Human Resources

\begin{tabular}{|c|c|c|c|c|c|c|c|}
\hline Model & $\mathbf{R}$ & R. Squal & & $\begin{array}{l}\text { Adjusted R. } \\
\text { Squared }\end{array}$ & $\begin{array}{l}\text { Std. Error of } \\
\text { the Estimate }\end{array}$ & Significance & Remark \\
\hline 1 & $0.69 \mathrm{a}$ & 0.48 & & 0.48 & 3.15 & & \\
\hline \multicolumn{8}{|l|}{ ANOVA } \\
\hline Model 1 & \multicolumn{2}{|c|}{ Sum of Square } & df & $\begin{array}{l}\text { Mean } \\
\text { Square }\end{array}$ & $\mathbf{F}$ & Significance & Remark \\
\hline Regression & \multicolumn{2}{|c|}{23279.49} & 1 & 23279.49 & 2344.04 & 0.00 & Significant \\
\hline Residual & \multicolumn{2}{|c|}{25106.44} & 2528 & 9.93 & & & \\
\hline Total & \multicolumn{2}{|c|}{48385.93} & 2529 & & & & \\
\hline \multicolumn{8}{|c|}{ VARIABLES IN THE EQUATION $^{\text {b }}$} \\
\hline Model & & B & SEB & Beta & $\mathbf{t}$ & Significance & Remark \\
\hline $\begin{array}{l}\text { Human } \\
\text { Managemen }\end{array}$ & $\begin{array}{l}\text { Resource } \\
\text { it }\end{array}$ & 0.49 & 0.01 & 0.69 & 48.42 & 0.00 & Significant \\
\hline
\end{tabular}

The data presented in table 1 shows that there is serious relationship between departmental heads, administrative strategies and their effective management of human resources in tertiary institutions $(r=0.69)$. The answer to research question 1, therefore, is that there is a strong positive intercorrelation between administrative strategies and human resource management.

The data in the table above (table 1) also shows $\mathrm{F}(1,2528)=2344.04, \mathrm{P}<0.05$. This indicates that there is a significant correlation between administrative strategies and human resource management. Hypothesis 1 is therefore rejected, and the alternative holds true. The adjusted $R^{2}$ value of 0.48 shows that $48 \%$ of the variable in 
human resource management was due to administrative strategies. Also, the relative degree of association of administrative strategies and human resource management is shown in the Beta $(\beta)$ weight (table 1$)$, and it indicates that human resource management is a strong predictor of administrative strategies.

\subsection{Research Question 2}

Is there any difference between the management of academic staff and the management of non-academic staff in tertiary educational institutions.

Hypothesis 2: There is no significant difference between the management of academic staff and the management of non-academic staff in tertiary educational institutions.

In order to answer this research question and test the hypothesis a group descriptive statistics and t-test was obtained for human resource management of both academic and non-academic staff of tertiary institution. The result is presented in table 2 .

Table 2. Independent Sample Test for Effective Human Resource Management for Academic and Non-Academic Staff

\begin{tabular}{lllllllll}
\hline & Staff Status & N & Mean & SD & $\begin{array}{l}\text { Std. } \\
\text { Error } \\
\text { Mean }\end{array}$ & df & t & Sign \\
& & & & & & & \\
\hline $\begin{array}{l}\text { Human Resources } \\
\text { Management }\end{array}$ & Academic & 980 & 43.58 & 5.86 & 0.19 & & & \\
& Non-Academic & 1550 & 43.87 & 6.46 & 0.16 & 2528 & -1.13 & .26 \\
\hline
\end{tabular}

The data in table 2, shows that there was no serious difference in scores for academic $(\mathrm{M}=43.58, \mathrm{SD}=5.86)$ and non-academic $(\mathrm{M}=43.87, \mathrm{SD}=6.46)$ in human resource management. This implies that both academic and non-academic staff perform similarly in terms of effective human resource management.

Since the significant value for levene's test of equality of variances is $<0.05$, then the equal variances are not assumed. Therefore, $\mathrm{t}(2230)=-1.16, \mathrm{P}=0.25$. That means, there is no significant difference between the human resource management of academic staff and the human resource management of non-academic staff in tertiary educational institutions. Hypothesis 2 is therefore retained. This means that the effectiveness of human resource management is similar for both academic and non-academic staff.

\subsection{Research Question 3}

To what extent do departmental heads' demographic factors predict their administrative strategies in tertiary educational institutions?

Hypothesis 3: Departmental heads' demographic factors do not significantly predict their administrative strategies in tertiary educational institution.

To answer the research question and test this hypothesis, a multiple correlation and regression analysis was conducted on administrative strategies and demographic factors (gender, rank, qualification, work experience, and institution of work). The results are presented in table 3 below.

Table 3. Multiple Correlation and Regression of Departmental Heads Administrative Strategies and their Demographic Factors

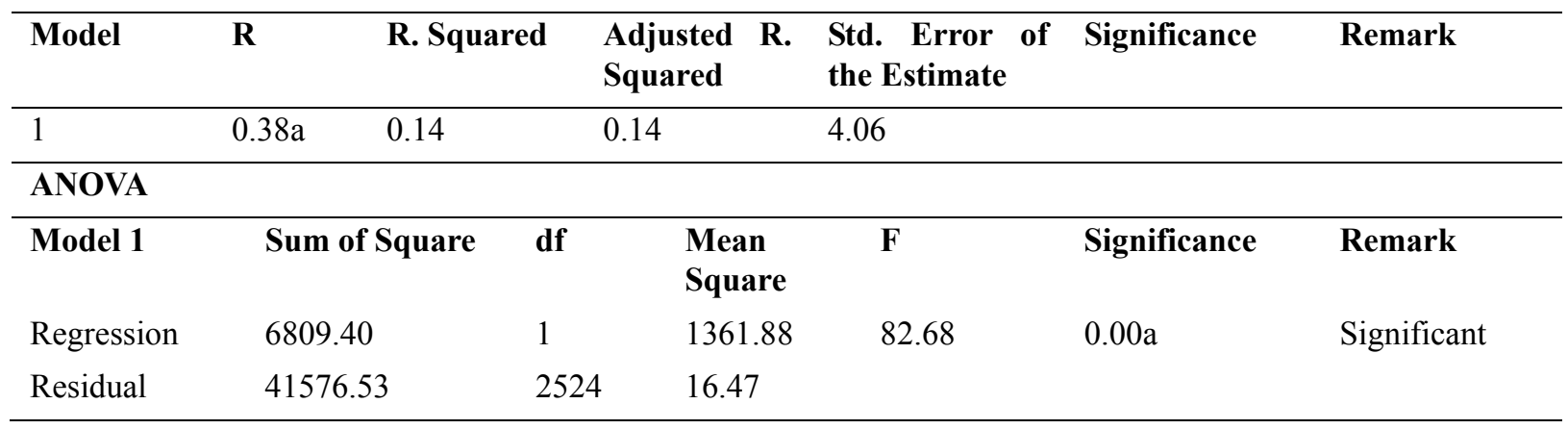




\begin{tabular}{|c|c|c|c|c|c|c|}
\hline Total & 48385.93 & 2529 & & & & \\
\hline \multicolumn{7}{|c|}{ VARIABLES IN THE EQUATION $^{\text {b }}$} \\
\hline Model & $\mathbf{B}$ & SEB & Beta & $\mathbf{t}$ & Significance & Remark \\
\hline (Constant) & 56.08 & 0.60 & - & 93.15 & 0.00 & Significant \\
\hline Gender & -2.00 & 0.30 & -0.15 & -6.80 & 0.00 & Significant \\
\hline Rank & 0.16 & 0.07 & 0.05 & 2.45 & 0.14 & Not Sign. \\
\hline Qualification & -0.31 & 0.11 & -0.06 & -2.82 & 0.01 & Significant \\
\hline Experience & 1.55 & 0.10 & 0.30 & 14.94 & 0.00 & Significant \\
\hline Institution & -0.04 & 0.09 & -0.01 & -0.45 & 0.65 & Not Sign. \\
\hline
\end{tabular}

a. Predictors: (Constant), gender, rank, qualification, experience and institution

b. Dependent Variable: Administrative Strategies.

The data in table 3 , shows that, $\mathrm{F}(5,2524)=82.68, \mathrm{P}<0.05$. This indicates that demographic factors of departmental heads (gender, rank, qualification, work experience, institution of work) significantly predict administrative strategies in tertiary institutions. Hypothesis 3 is therefore rejected, and the alternative holds true. The adjusted $\mathrm{R}^{2}$ value of 0.14 , shows that only $14 \%$ of the variance in administrative strategies was due to the collective impacts of gender, rank, qualification, work experience and institution of work. The relative degree of association of gender, rank, qualification, work experience, institution of work and administrative strategies is shown in the Beta $(\beta)$ weight in table 3. The significant "constant" $t$-value $(93.15, \mathrm{P}<0.05)$ showed that there were some other variables which were not included in this study. The results of the beta value for the variables suggest that gender, qualification, work experience and institution of work are strong predictors of administrative strategies among departmental heads.

\subsection{Research Question 4}

To what extent do departmental heads' demographic factors combined (gender, rank, qualification, experience, institution) predict their effective management of human resources in tertiary educational institutions?

Hypothesis 4: Departmental heads demographic factors do not significantly predict their effective management of human resources in tertiary educational institutions.

To answer the research question and test the hypothesis, a multiple correlation and regression analysis was performed with effective management of human resources and demographic factors of departmental heads which include gender, rank, qualification, experience and institution of work. The results are presented in table 4.

Table 4. Multiple correlation and regression analysis of departmental heads effective management of human resources and demographic factors

\begin{tabular}{|c|c|c|c|c|c|c|c|}
\hline Model & $\mathbf{R}$ & \multicolumn{2}{|c|}{ R. Squared } & $\begin{array}{l}\text { Adjusted R. } \\
\text { Squared }\end{array}$ & $\begin{array}{l}\text { Std. Error of } \\
\text { the Estimate }\end{array}$ & Significance & Remark \\
\hline 1 & $0.39 \mathrm{a}$ & 0.16 & & 0.15 & 5.74 & 0.00 & Significant \\
\hline \multicolumn{8}{|l|}{ ANOVA } \\
\hline Model 1 & Sum & f Square & df & $\begin{array}{l}\text { Mean } \\
\text { Square }\end{array}$ & $\mathbf{F}$ & Significance & Remark \\
\hline Regression & 1529 & 27.40 & 5 & 3058.65 & 92.93 & $0.00 \mathrm{a}$ & Significant \\
\hline Residual & 8307 & & 2524 & 32.92 & & & \\
\hline Total & 9836 & & 2529 & & & & \\
\hline \multicolumn{8}{|c|}{ VARIABLES IN THE EQUATION $^{\text {b }}$} \\
\hline Model & & B & SEB & Beta & $\mathbf{t}$ & Significance & Remark \\
\hline (Constant) & & 32.98 & 0.85 & - & 38.76 & 0.00 & Significant \\
\hline Gender & & 4.12 & 0.42 & 0.22 & 9.88 & 0.00 & Significant \\
\hline
\end{tabular}




\begin{tabular}{lllllll}
\hline Rank & 0.16 & 0.09 & 0.13 & 6.64 & 0.00 & Significant \\
Qualification & -1.87 & 0.15 & -0.27 & -12.18 & 0.00 & Significant \\
Experience & 1.03 & 0.15 & 0.14 & 7.04 & 0.00 & Significant \\
Institution & 1.54 & 0.13 & 0.24 & 12.09 & 0.00 & Significant \\
\hline
\end{tabular}

a. Predictors: (Constant), rank, gender, qualification, experience, institution of work

b. Dependent Variable: Human resource management.

The data in table 4 shows that $\mathrm{F}(5,2524)=92.93, \mathrm{P}<0.05$. This indicates that demographic factors of departmental heads significantly predict their effective management of human resources in tertiary educational institutions. Therefore, hypothesis 4 is rejected and the alternative holds true. The adjusted $\mathrm{R}^{2}$ value of 0.15 shows that only $15 \%$ of the variance in effective management of human resources was due to the collective impact of gender, rank, qualification, experience and institution of work (demographic factors). The relative degree of association of these demographic factors and effective human resource management is shown in the Beta $(\beta)$ weight in table 4 . The result shows that qualification is a stronger predictor of effective management of human resource and of all other demographic factors of departmental heads. The significant "constant" t-value $(38.78, \mathrm{P}<0.05)$ shows that there were some other potent variables which were not included in this study.

\section{Discussion of Results}

On research question one, the study discovered that there is a strong positive inter-correlation between administrative strategies and human resource management. Also, on hypothesis one, it was found that there is significant correlation between administrative strategies and human resources management. This indicates that human resource management is a strong predictor of administrative strategies. This finding is in line with Banabo, et al (2011) who are of the view that all the major skills of motivation, training and development, staffing, employee's maintenance need to be emphasized by administrators in time of management.

Results on research question two shows that both academic and non-academic staff perform similarly in terms of effective human resource management. Hypothesis two which stated that there is no significant difference between the management of academic and non-academic staff was retained which means that effectiveness of human resource management is similar for both academic and non-academic staff. This finding is in agreement with that of Adeyemo (2008) who discovered that there is no significant difference between the management of teaching and non-teaching staff in secondary schools.

On research question three, it was observed that significant positive correlation exists between departmental heads demographic factors and their administrative strategies. This indicates that increase in one variable leads to improvement in the other variable, while, on the other hand, the significant negative correlation indicates that an increase in one variable leads to decrease in the other. Hypothesis three result indicates that demographic factors of departmental heads significantly predict their administrative strategies in tertiary institutions, hence the hypothesis was rejected.

It was observed concerning research question four that a significant positive correlation exists between human resources and some demographic factors, while a significant negative correlation exists between human resources and other demographic variables. The positive correlation between some variables suggests that an increase in one variable leads to an increase in the other, while a negative correlation indicates that an increase in one variable leads to a decrease in other variables. Hypothesis four results showed that demographic factors of departmental heads significantly predict their effective management of human resources in tertiary institutions. The result also showed that qualification is a stronger predictor of effective management of human resource and of all other demographic factors. Furthermore, the significant "constant" t-value showed there were some other potent variables which were not included in this study.

\section{Conclusion}

Considering the findings of the study, it was concluded that there is positive significant correlation between administrative strategies and human resource management. It was also concluded that the effectiveness of human resource management for both academic and non-academic staff is similar because hypothesis two was retained.

It is worthy of note as well that departmental heads demographic factors predict their administrative strategies; so also is their effective management of human resources. 


\section{Recommendations}

Based on the findings of this study, it is recommended that departmental heads should equip themselves adequately with various administrative strategies such as effective planning, organization, directing, motivation, controlling, proper delegation of duty, effective leadership, supervision, monitoring, communication, and effective disciplinary ability since these strategies have a lot of influence on the effective management of human resources.

School authorities of tertiary institutions should support and intensify efforts at training and retraining departmental heads on strategies that would boost effective management of academic and non-academic staff.

\section{References}

Adesina, S. (2007). Some aspect of school management. Lagos: Educational Publishing Industry Limited.

Adeyemi, T. O. (2008). The influence of administrative strategies on the effective management of human resources in secondary schools in Ondo State, Nigeia. International Journal Studies in Educational Administration. Journal of the Commonwealth Council for Educational Administration and Management, $36(2), 80-90$.

Ajayi, I. O., \& Ayodele, J. B. (2002). Fundamentals of educational management. Ado-Ekiti: Greenline Publishers.

Banabo E., Nsiomu, K., \& Koroye, B. (2011). Human resources management skills required of tertiary institution administrators in the Niger Delta States of Nigeria. Current Research Journal of Social Sciences, $3(\mathrm{~b}), 432-444$.

Egwunyenga, E. J. (2006). Essential of school administration. Benin City: Justice Jeco Publishers.

Fabunmi, F. A. (2000). Application of management principles to the administration of primary school libraries in Nigeria, African Journal of Educational Management, 8(1), 92-244.

Haslinda, A. (2009). Major challenges to the effective management of human resource training and development activities. The Journal of International Social Research, 2(8).

National Policy on Education. (2004). Federal Government of Nigeria (2004), National Policy on Education (3rd ed.). Lagos: Federal Ministry of Education NEDC.

Oyedeji, N. B. (2000). Management in education: Principles and practice. Lagos: Aras Publishers.

Oyeniyi, O. I. (2011). Human resource management in Nigerian universities (Unpublished Ph.D. Thesis of the Faculty of Education, Delta State University, Abraka).

Tijani, M. N. (2011). The need for action-driven vision and sustainable management of water resources in Nigeria. Journal of Mining and Geology, 42(1), 31-40.

Wikipedia. (2012). Human resource management. Wikipedia the free encyclopedia Retrieved May 27th, 2012, from http://en.wikipedia.org/wiki/human-resource-management-cached

\section{Copyrights}

Copyright for this article is retained by the author(s), with first publication rights granted to the journal.

This is an open-access article distributed under the terms and conditions of the Creative Commons Attribution license (http://creativecommons.org/licenses/by/3.0/). 